\title{
Biosorption of chromium (VI) from aqueous solutions by the husk of Bengal gram (Cicer arientinum)
}

\author{
N. Ahalya \\ Energy and Wetlands Research Group \\ Centre for Ecological Sciences \\ Indian Institute of Science \\ Bangalore 560 012, India \\ Tel: 91080 23600985/22932506 \\ Fax: 91-08023601428 \\ E-mail: Ahalya@ces.iisc.ernet.in \\ R.D. Kanamadi \\ Department of Zoology \\ Karnataka University, Dharwad, India \\ Tel: $918362215225 / 2215355$ \\ Fax 91-836-2747884 / 2741928 \\ E-mail: ravishankar_kanamadi@yahoo.com \\ T.V. Ramachandra* \\ Energy and Wetlands Research Group \\ Centre for Ecological Sciences \\ Indian Institute of Science \\ Bangalore 560 012, India \\ Tel: 91080 22933099/23600985/22932506/22932786 \\ Fax: 91080 23601428/23600085/23500683 \\ E-mail: cestvr@ces.iisc.ernet.in
}

\begin{abstract}
Financial support: This research has been carried out with the financial assistance from the Ministry of Environment and Forests, Government of India and Indian Institute of Science.
\end{abstract}

Keywords: agro-wastes, Bengal gram husk (bgh), Cicer arientinum, chromium biosorption, isotherms, fourier transform infrared spectroscopy (FTIR).

Abbreviations: bgh: Bengal gram husk

FTIR: fourier transform infrared spectroscopy

The potential to remove $\mathrm{Cr}$ (VI) from aqueous solutions through biosorption using the husk of Bengal gram (Cicer arientinum), was investigated in batch experiments. The results showed removal of $99.9 \%$ of chromium in the $10 \mathrm{mgl}^{-1}$ chromium solution, the biomass required at saturation was $1 \mathrm{~g} \mathrm{mg}^{-1}$. Kinetic experiments revealed that the dilute chromium solutions reached equilibrium within $180 \mathrm{~min}$. The biosorptive capacity of the (bgh) was dependent on the $\mathrm{pH}$ of the chromium solution, with $\mathrm{pH} 2$ being optimal. The adsorption data fit well with the Langmuir and Freundlich isotherm models. The adsorption capacity calculated from the Langmuir isotherm was $91.64 \mathrm{mg}$ $\mathrm{Cr}$ (VI)/g at pH 2. The adsorption capacity increased with increase in agitation speed and an optimum was achieved at $120 \mathrm{rpm}$. The biosorption of $\mathrm{Cr}$ (VI) was studied by Fourier transform infrared spectroscopy (FTIR), which suggested that the presence of Cr (VI) ions in the biomass affects the bands corresponding to hydroxyl and carboxyl groups. Comprehensive characterisation of parameters indicates bgh to be an excellent material for biosorption of $\mathrm{Cr}$ (VI) to treat wastewaters containing low concentration of the metal.

The discharge of heavy metals into aquatic ecosystems has become a matter of concern over the last few decades. The pollutants of serious concern include lead, chromium, mercury, uranium, selenium, zinc, arsenic, cadmium, gold, silver, copper, nickel, etc. due to pollutants' carcinogenic and mutagenic nature. These toxic materials may be derived from mining operations, refining ores, sludge disposal, fly ash from incinerators, the processing of radioactive materials, metal plating, or the manufacture of electrical equipment, paints, alloys, batteries, pesticides or preservatives.

The commonly used procedures for removing metal ions from effluents include chemical precipitation, lime coagulation, ion exchange, reverse osmosis and solvent

\footnotetext{
* Corresponding author
} 
extraction (Juang and Shiau, 2000; Yan and Viraraghavan, 2001). These techniques apart from being economically expensive have disadvantages like incomplete metal removal, high reagent and energy requirements, and generation of toxic sludge or other waste products that require disposal. Efficient and environment friendly methods are thus needed to be developed to reduce heavy metal content

Table 1. Type of Isotherm for various $R_{L}$.

\begin{tabular}{|c|c|}
\hline $\mathbf{R}_{\mathbf{L}}$ & Type of isotherm \\
\hline $\mathrm{R}_{\mathrm{L}}>1$ & Unfavourable \\
\hline $\mathrm{R}_{\mathrm{L}}=1$ & Linear \\
\hline
\end{tabular}

In this context, considerable attention has been focused in recent years upon the field of biosorption for the removal of heavy metal ions from aqueous effluents (Volesky and Holan, 1995). The process of heavy metal removal by biological materials is known as biosorption. Biomass viability does not affect the metal uptake. Therefore any active metabolic uptake process is currently considered to be a negligible part of biosorption. Various biosorbents have been tried, which include seaweeds, moulds, yeast, bacteria, crab shells, agricultural products such as wool, rice, straw, coconut husks, peat moss, exhausted coffee (Dakiky et al. 2002), waste tea (Amir et al. 2005), walnut skin, coconut fibre (Espinola et al. 1999), cork biomass (Chubar et al. 2003), seeds of Ocimum Basilicum (Melo and d'Souza, 2004), defatted rice bran, rice hulls, soybean hulls and cotton seed hulls (Marshall and Champagne, 1995, Teixeria and Zezzi, 2004), wheat bran, hardwood (Dalbergia sissoo) sawdust, pea pod, cotton and mustard seed cakes, (Iqbal et al. 2002, Saeed et al. 2002).

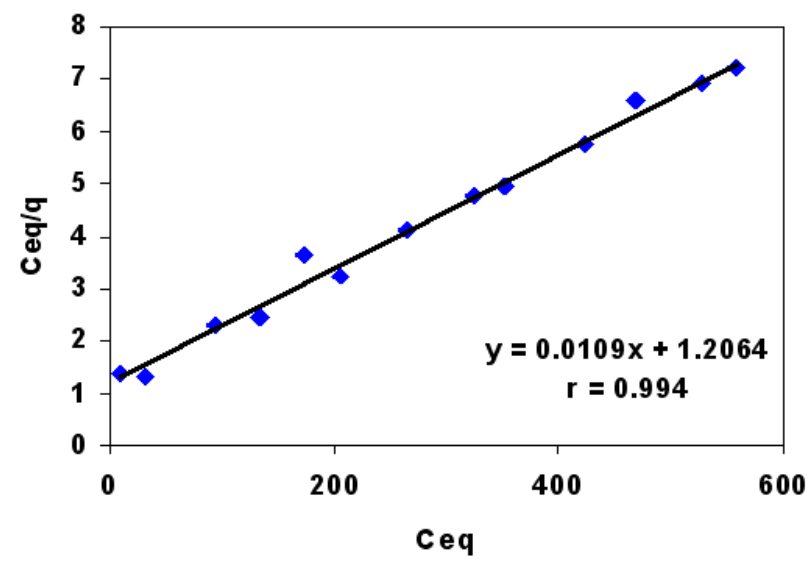

Figure.1. Langmuir adsorption isotherm for $\mathrm{Cr}$ (VI) hinsorntion hv hah at ontimum conditions

Chromium is a toxic metal of widespread use and exists in several oxidation states. The most stable and common forms are the trivalent $\mathrm{Cr}$ (III) and the hexavalent $\mathrm{Cr}$ (VI) species, which display quite different chemical properties. $\mathrm{Cr}$ (VI) considered to be the most toxic of chromium, is usually associated with oxygen as chromate $\left(\mathrm{CrO}_{4}^{2-}\right)$ or dichromate $\left(\mathrm{Cr}_{2} \mathrm{O}_{7}{ }^{2-}\right)$ ions. The hexavalent form of chromium is considered to be a group " $\mathrm{A}$ " human carcinogen because of its mutagenic and carcinogenic properties (Cieslak-Golonka, 1995). Cr (VI) is a common pollutant introduced into natural waters from a variety of industrial wastewaters including those from the textile dyeing, leather tanning, electroplating and metal finishing industries. The untreated effluent from electroplating industry contains approximately $100 \mathrm{mg} / \mathrm{l} \mathrm{Cr}$ (VI), which is much higher than the permissible limit of $0.05-1 \mathrm{mg} / \mathrm{l}$ (De Filippis and Pallaghy, 1994).

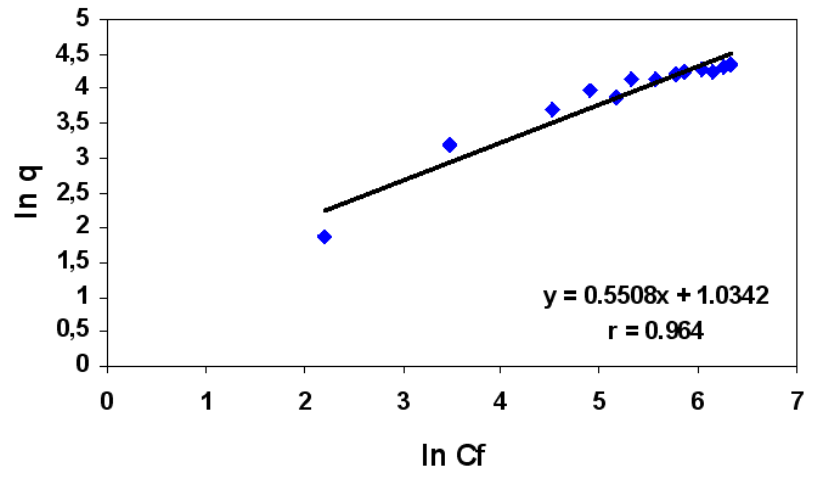

Figure 2. Freundlich adsorption isotherm for $\mathrm{Cr}$ (VI) biosorption by bgh at optimum conditions.

In the present study, Bengal gram husk (bgh) (Cicer arientinum), which is a milling agrowaste available in plenty in a tropical country like India is used for the removal of $\mathrm{Cr}(\mathrm{VI})$ ions from aqueous solutions.

\section{MATERIALS AND METHODS}

\section{Biosorbent material}

Bengal gram husk (bgh), seed coat of Cicer arientinum was collected from a legume seed-splitting mill. The bgh was washed extensively in running tap water to remove dirt and other particulate matter. Washing and boiling in distilled water repeatedly to remove colour followed this. The washed and boiled bgh was oven dried at $105^{\circ} \mathrm{C}$ for $24 \mathrm{hrs}$, stored in dessicator and used for biosorption studies in the original piece size.

\section{Preparation of stock solution}

An aqueous stock solution (1000 mg/l) of $\mathrm{Cr}$ (VI) ions was prepared using $\mathrm{K}_{2} \mathrm{Cr}_{2} \mathrm{O}_{7}$ salt. $\mathrm{pH}$ of the solution was adjusted using $0.1 \mathrm{~N} \mathrm{HCl}$ or $\mathrm{NaOH}$. Fresh dilutions were used for each study.

\section{Biosorption studies}

The biosorption capacity of bgh was determined by 
contacting various concentrations $\left(10-100 \mathrm{mgl}^{-1}\right)$ of 100 $\mathrm{ml} \mathrm{Cr}$ solution in $250 \mathrm{ml}$ conical flasks, with 1 gram of bgh. The mixture was shaken in a rotary shaker at $120 \mathrm{rpm}$ followed by filtration using Whatman filter paper (No. 1). The filtrate containing the residual concentration of $\mathrm{Cr}$ was determined spectrophotometrically at $540 \mathrm{~nm}$ after complexation with 1,5 diphenylcarbazide (Eaton et al. 1995). For the determination of rate of metal biosorption by bgh from $100 \mathrm{ml}$ (at 10, 20, 50, $100 \mathrm{mgl}^{-1}$ ), the supernatant was analysed for residual $\mathrm{Cr}$ after the contact period of 15 , $30,60,120,180,240$ and $300 \mathrm{~min}$. The effect of $\mathrm{pH}$ on $\mathrm{Cr}$ sorption by bgh was determined at $\mathrm{pH}$ values of $2,3,4,5,6$ and 7. The effect of different doses of bgh ranging from 1 to $40 \mathrm{~g} / \mathrm{l}$ at varied $\mathrm{Cr}$ (VI) concentrations was determined.

Adsorption isotherm studies were carried out with thirteen different initial concentrations ranging from 20 to $600 \mathrm{mg} / 1$ of $\mathrm{Cr}$ (VI) while maintaining the adsorbent dosage at 1g/100ml. Langmuir and Freundlich models were applied to the adsorption isotherm and different constants were generated. The Langmuir and Freundlich adsorption parameters and correlation coefficient were also calculated from the adsorption isotherm data.

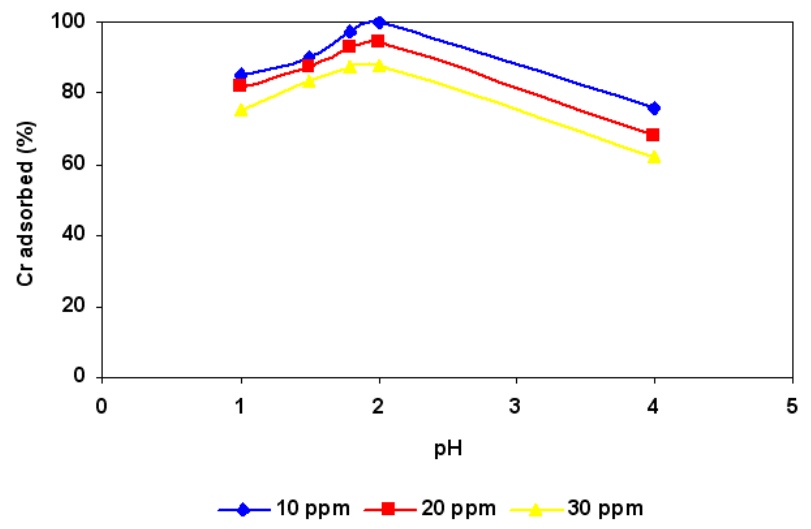

Figure 3. Effect of $\mathrm{pH}$ on the biosorption of $\mathrm{Cr}(\mathrm{VI})$ at different concentrations, by $10 \mathrm{gl}^{-1}$ at $120 \mathrm{rpm}$ with equilibrium time of $200 \mathrm{~min}$.

\section{Infrared spectra analysis}

In order to determine the functional groups responsible for metal uptake, an un-reacted bgh sample and bgh pre-treated with $100 \mathrm{mg} / \mathrm{l}$ chromium solution were analysed using a Fourier transform infrared spectrometer (FTIR). FTIR technique is used mainly to identify functional groups (like carboxyl, hydroxyl, etc.) that are capable of adsorbing metal ions.

All the experiments were carried out in triplicate and the mean values with standard deviation are presented. The maximum deviation was $2.0 \%$ (standard deviation $\pm 2 \%$ ).

\section{RESULTS AND DISCUSSION}

\section{Sorption equilibria studies}

The chromium uptake capacity of the bgh was evaluated using the Langmuir and Freundlich adsorption isotherms. The Langmuir isotherm represents the equilibrium distribution of metal ions between the solid and liquid phases. The following equation can be used to model the adsorption isotherm:

$$
q=\frac{q_{\max } b C_{e q}}{1+b C_{e q}}
$$

where $\mathrm{q}$ is milligrams of metal accumulated per gram of the biosorbent material; $\mathrm{C}_{\mathrm{eq}}$ is the metal residual concentration in solution; $\mathrm{q}_{\max }$ is the maximum specific uptake corresponding to the site saturation and $\mathrm{b}$ is the ratio of adsorption and desorption rates (Chong and Volesky, 1995). The Langmuir isotherm is based on these assumptions (Langmuir, 1918).

- metal ions are chemically adsorbed at a fixed number of well defined sites;

- each site can hold only one ion;

- all sites are energetically equivalent and;

- there is no interaction between the ions.

When the initial metal concentration rises, adsorption increases while the binding sites are not saturated. The linearised Langmuir isotherm allows the calculation of adsorption capacities and the Langmuir constants and is equated by the following equation.

$$
\mathrm{C}_{\mathrm{eq}} / \mathrm{q}=1 / \mathrm{q}_{\max } \cdot \mathrm{b}+\mathrm{C}_{\mathrm{eq}} / \mathrm{q}_{\max }
$$

The linear plots of $\mathrm{C}_{\mathrm{eq}} / \mathrm{q}$ vs $\mathrm{C}_{\mathrm{eq}}$ show that adsorption follows the Langmuir adsorption model (Figure 1) The correlation coefficient is 0.9948 (regression coefficient 0.9896). $\mathrm{q}_{\max }$ and $\mathrm{b}$ were determined from the slope and intercept of the plot and were found to be $91.64 \mathrm{mg} / \mathrm{g}$ and $0.009 \mathrm{l} / \mathrm{mg}$ respectively.

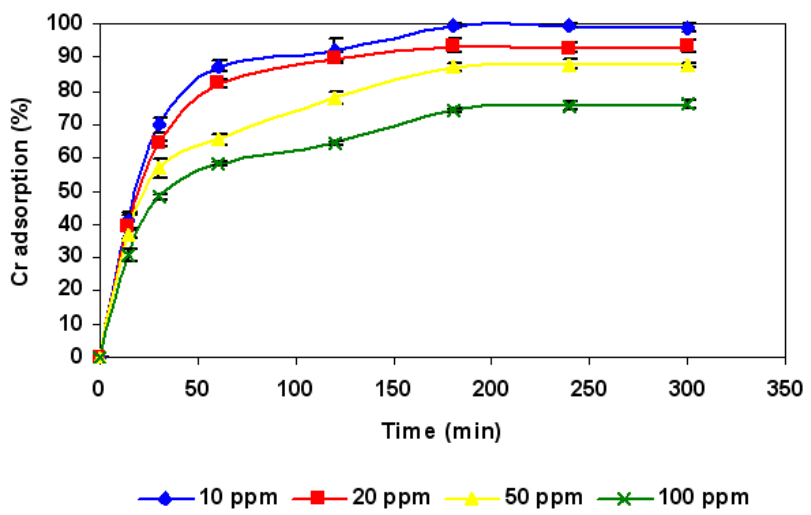

Figure 4. Percentage biosorption of $\mathrm{Cr}$ (VI) from solution of

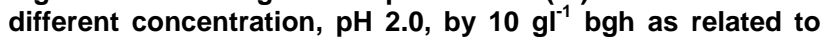
the time of contact at $120 \mathrm{rpm}$.

The essential characteristics of the Langmuir isotherms can be expressed in terms of a dimensionless constant separation factor or equilibrium parameter, $\mathrm{R}_{\mathrm{L}}$, which is defined as: 


$$
\mathrm{R}_{\mathrm{L}}=1 /\left(1+\mathrm{bC}_{\mathrm{o}}\right)
$$

Where $\mathrm{b}$ is the Langmuir constant and $\mathrm{C}_{\mathrm{o}}$ is the initial concentration of $\mathrm{Cr}(\mathrm{VI})$. The $\mathrm{R}_{\mathrm{L}}$ value indicates the shape of isotherm as given in Table 1.

According to McKay et al. (1982), $\mathrm{R}_{\mathrm{L}}$ values between 0 and 1 indicate favourable adsorption. The $\mathrm{R}_{\mathrm{L}}$ were found to be 0.8475 to 0.15625 for concentrations of $20-600 \mathrm{mg} / \mathrm{l} \mathrm{Cr}$ (VI).

The Freundlich isotherm is represented by the equation (Freundlich, 1907):

$$
\mathrm{q}=\mathrm{K}_{\mathrm{f}} \mathrm{C}_{\mathrm{eq}}^{1 / \mathrm{n}}
$$

where $\mathrm{C}_{\mathrm{eq}}$ is the equilibrium concentration $(\mathrm{mg} / \mathrm{l})$, $\mathrm{q}$ is the amount adsorbed $(\mathrm{mg} / \mathrm{g})$ and $\mathrm{K}_{\mathrm{f}}$ and $\mathrm{n}$ are constants incorporating all parameters affecting the adsorption process, such as adsorption capacity and intensity respectively. The linearised forms of Freundlich adsorption isotherm was used to evaluate the sorption data and is represented as:

$$
\ln q=\ln K_{f}+1 / n \ln C_{e q}
$$

$\mathrm{K}_{\mathrm{f}}$ and $\mathrm{n}$ were calculated from the slopes of the Freundlich plots (Figure 2) The constants were found to be $K_{f}=2.815$ and $\mathrm{n}=1.814$. According to Kadirvelu and Namasivayam (2000), $\mathrm{n}$ values between 1 and 10 represent beneficial adsorption.

The comparison of Freundlich constants with adsorption capacity for $\mathrm{Cr}$ (VI) with other adsorbents is given in Table 2.

Figure 1 and Figure 2 conforms with the Langmuir and Freundlich models. The Langmuir capacity or $\mathrm{q}_{\max }$ is used to compare the efficiency of bgh with other materials, which have been tested as biosorbents for $\mathrm{Cr}$ (VI). Table 2 shows that, for $\mathrm{Cr}(\mathrm{VI})$, the bgh has a greater capacity than some of the materials. The magnitude of $\mathrm{K}_{\mathrm{f}}$ and $\mathrm{n}$ shows easy separation of heavy metal ion from wastewater and high adsorption capacity. The value of $\mathrm{n}$, which is related to the distribution of bonded ions on the sorbent surface, is found to be greater than unity for bgh, indicating that adsorption of $\mathrm{Cr}$ (VI) is favourable.

\section{Effect of Ph}

Chromium exhibits different types of $\mathrm{pH}$ dependent equilibria in aqueous solutions. As the $\mathrm{pH}$ is shifted, the equilibrium will also shift; in the $\mathrm{pH}$ range $2-6, \mathrm{HCrO}_{4}{ }^{-}$, and $\mathrm{Cr}_{2} \mathrm{O}_{7}{ }^{2-}$, ions are in equilibrium. At lower $\mathrm{pH}(\mathrm{pH}<2.0)$ values, $\mathrm{Cr}_{3} \mathrm{O}_{10}{ }^{-}$and $\mathrm{Cr}_{4} \mathrm{O}_{13}{ }^{2-}$ species are formed. The optimum initial $\mathrm{pH}$ for biosorption of hexavalent chromium on to bgh (husk of Cicer arientinum) was observed at $\mathrm{pH}$ 2.0. This indicates the formation of more polymerized chromium oxide species with decreased $\mathrm{pH}$.

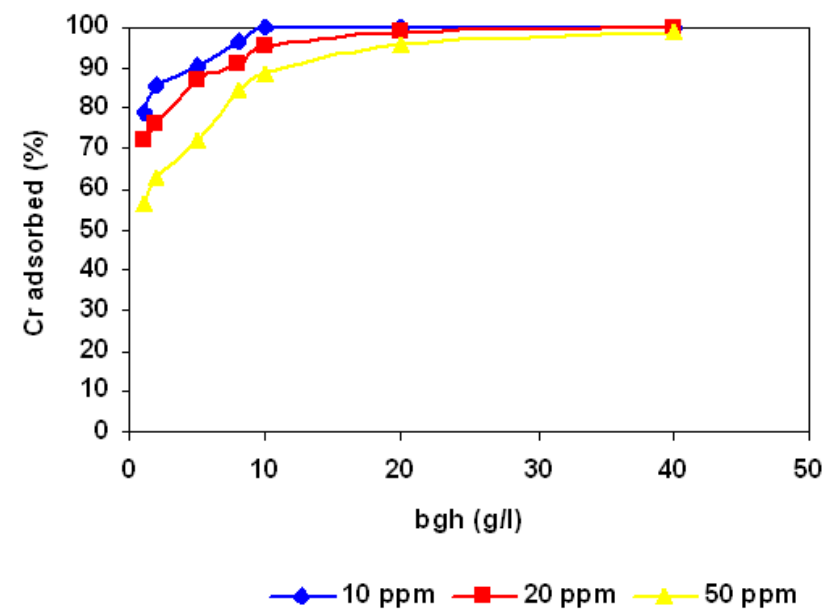

Figure 5. Effect of quantity of bgh biomass on biosorption of $\mathrm{Cr}$ (VI) from solutions of different concentrations, $\mathrm{pH} 2.0$ for contact time $200 \mathrm{~min}$ at $120 \mathrm{rpm}$.

As illustrated in Figure 3, 99.6\% of $\mathrm{Cr}$ ions was adsorbed from a solution of $10 \mathrm{mg} / \mathrm{l}$ at $\mathrm{pH} 2.0$, whereas a $23 \%$ reduction in biosorption was determined as the $\mathrm{pH}$ shifted from 2.0 to 4.0. The percentage of $\mathrm{Cr}$ ions adsorbed at $\mathrm{pH}$ 2.0 decreased with increasing metal concentration. The adsorption of metal ions depends on solution $\mathrm{pH}$, which influences electrostatic binding of ions to corresponding metal groups. At the optimum sorption $\mathrm{pH} 2.0$, the dominant species of $\mathrm{Cr}$ ions in solution are $\mathrm{HCrO}_{4}^{-}, \mathrm{Cr}_{2} \mathrm{O}_{7}^{2-}$, $\mathrm{Cr}_{4} \mathrm{O}_{13}{ }^{2-}$ and $\mathrm{Cr}_{3} \mathrm{O}_{10}{ }^{2-}$. These chromate anions interact strongly with the negatively charged ions of the bgh matrix.

\section{Biosorption Kinetics and effect of biomass quantity on chromium uptake by bgh}

The concentration of both the metal ions and the biosorbent is a significant factor to be considered for effective biosorption. It determines the sorbent/sorbate equilibrium of the system. The rate of adsorption is a function of the initial concentration of ions. The kinetic profiles of the chromium biosorption at various concentrations are shown in Figure 4. The system attained equilibrium, although not

Table 2. Comparison of adsorption capacity and Freundlich isotherm constants for $\mathrm{Cr}(\mathrm{VI})$ with other adsorbents.

\begin{tabular}{|l|c|c|c|c|}
\hline Adsorbent & $\mathbf{K}_{\mathbf{f}}$ & $\mathbf{1 / n}$ & $\mathbf{q}_{\max }$ & Reference \\
\hline Rhizopus arrhizus & 10.99 & 0.18 & 23.88 & Prakasham et al. 1999 \\
\hline Rhizopus nigrificans & 12.06 & 3.24 & 99.00 & Bai and Abraham, 2001 \\
\hline Chlorella vulgaris & 0.48 & 1.26 & 33.80 & Cetinkaya et al. 1999 \\
\hline Scenedesmus obliquus & 0.68 & 1.42 & 30.20 & Cetinkaya et al. 1999 \\
\hline Synechocystis sp. & 1.54 & 1.40 & 39.00 & Cetinkaya et al. 1999 \\
\hline Cone biomass & 38.38 & 0.35 & 201.81 & Ucun et al. 2002 \\
\hline Bengal gram husk & 2.815 & 1.814 & 91.64 & This study \\
\hline
\end{tabular}


as fast as reported in other concentrations.

The time taken to attain equilibrium for 10, 20, 50 and 100 $\mathrm{mg} / \mathrm{l}$ chromium solution were $180 \mathrm{~min}$. But as the chromium concentration increased, the percentage of chromium biosorption progressively decreased from $99.65 \%$ in $10 \mathrm{mg} / 1$ to $75 \%$ in $100 \mathrm{mg} / 1$ solution, even though the sorption equilibrium was achieved during the same period of $180 \mathrm{~min}$. This appears to be due to the increase in the number of ions competing for the available binding sites in the biomass and also due to the lack of binding sites for the complexation of $\mathrm{Cr}$ ions at higher concentration levels. At lower concentrations, all metal ions present in the solution would interact with the binding sites and thus facilitated $100 \%$ adsorption. At higher concentrations, more $\mathrm{Cr}$ ions are left unabsorbed in solution due to the saturation of binding sites. The agitation time was fixed at $200 \mathrm{~min}$ for the rest of the experiments.

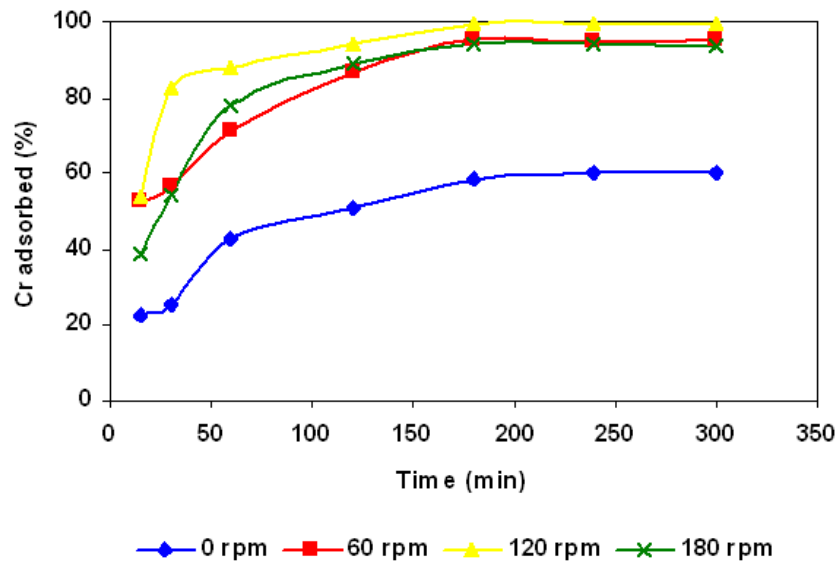

Figure 6. Effect of agitation speed on $\mathrm{Cr}(\mathrm{VI})$ adsorption, $\mathrm{Cr}$ concentration $=50 \mathrm{mgl}^{-1}, \mathrm{pH}=2.0, \mathrm{bgh}$ dose $=10 \mathrm{gl}^{-1}$.

For the confirmation of this decline to be due to the saturation of the sorption sites, bgh biomass was varied from 1 to $40 \mathrm{~g} / \mathrm{l}$ and brought in contact with chromium solutions of different concentrations. For $99 \%$ removal of chromium from 10, 20 and $50 \mathrm{mg} / \mathrm{l}$ metal solutions, the bgh biomass required was 10,20 and $40 \mathrm{~g} / \mathrm{l}$ at approximate ratio of 1:1000. The rate of increase of chromium removal was not proportionate to the increase in bgh biomass, (Figure 5). This could be attributed to interference between binding sites at higher concentrations (Puranik and Paknikar, 1999). Higher chromium sorption at lower levels of bgh biomass could be due to the higher metal to biosorbent ratio, which decreases as the biomass quantity is increased (Puranik and Paknikar, 1999).

\section{Effect of agitation speed}

The effect of the agitation of the sorbent/sorbate system in $\mathrm{Cr}$ adsorption was monitored at low, medium and high speed of agitation using a non-agitated system as the control.

All agitation speeds were found to have a positive impact over the non-agitated system as shown in Figure 6. A 30 $40 \%$ increase in adsorption was observed in agitated samples during $120 \mathrm{~min}$ of biosorption. This is because agitation facilitates proper contact between the metal ions in solution and the biomass binding sites and thereby promotes effective transfer of sorbate ions to the sorbent sites. At 60 and $180 \mathrm{rpm}$, the adsorption rates monitored were found to be slightly lower than that at $120 \mathrm{rpm}$. These results indicate that the contact between solid and liquid is more effective at moderate agitation (120 rpm). This observation agrees with the previously reported biosorptive removal of Cr (VI) by Rhizopus arrhizus (Niyogi et al. 1998) and Rhizopus nigricans (Bai and Abraham, 2003), where 100 and $120 \mathrm{rpm}$ respectively were found to be the optimum speed.

Table 3. IR absorption bands and corresponding possible groups.

\begin{tabular}{|c|c|}
\hline Frequencv $\left(\mathbf{c m}^{-1}\right)$ & Functional aroup \\
\hline 3437.38 & $-\mathrm{OH},-\mathrm{NH}$ \\
\hline 2918.89 & $-\mathrm{CH}$ \\
\hline 2844.78 & $-\mathrm{CH}$ \\
\hline 1634.34 & $-\mathrm{COO},-\mathrm{C}=\mathrm{O}$ \\
\hline 1115.57 & $-\mathrm{C}-\mathrm{O}, \mathrm{C}-\mathrm{N}$ \\
\hline 893.25 & $-\mathrm{CH}$ \\
\hline
\end{tabular}

\section{Infra red spectral analysis}

An un-reacted bgh sample and bgh pre-treated with 100 $\mathrm{mg} / \mathrm{l} \mathrm{Cr}$ (VI) solution were analysed using FTIR, and the percentage transmission for various wave numbers are presented in Figure 7 and Figure 8 respectively. The absorption bands identified in the spectra and their assignment to the corresponding functional groups in the bgh are listed in Table 3.

Wave number of 3000 and $3750 \mathrm{~cm}^{-1}$ for bgh indicates the presence of $\mathrm{OH}$ groups on the husk surface. The trough that is observed at $2918.18 \mathrm{~cm}^{-1}$ and $893.25 \mathrm{~cm}^{-1}$ indicates the presence of $\mathrm{C}-\mathrm{H}$ groups. The $1634.34 \mathrm{~cm}^{-1}$ band is a result of $\mathrm{CO}$ stretching mode, conjugated to a $\mathrm{NH}$ deformation mode and is indicative of amide 1 band. The trough at $1115.57 \mathrm{~cm}^{-1}$ is due to $\mathrm{CO}$ or $\mathrm{CN}$ groups. This reveals the presence of several functional groups for binding $\mathrm{Cr}$ (VI) ions on bgh surface.

\section{CONCLUDING REMARKS}

Biosorption observations on the ability of bgh to remove $\mathrm{Cr}$ (VI) indicate the biomass of having potential of application to sequester heavy metals from low concentration waste waters. Containing approximately $52 \%$ crude fibre composed of cellulose, hemicellulose and lignin, the bgh biomatrix indicates the presence of many - $\mathrm{OH}$ and $\mathrm{COOH}$ groups in the linocellulosic moieties. Hydrogen of these groups is capable of ion exchange with metal cations. 


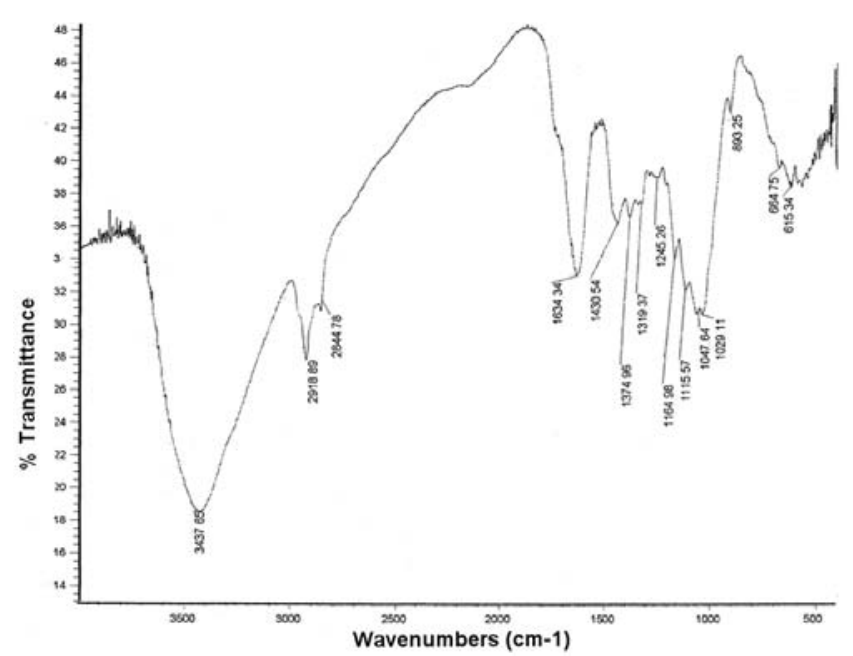

Figure 7. Infrared spectra of untreated bgh.

Protein content in bgh is less than 5\%, which is advantageous over the protein rich algal and fungal biomass projected as metal biosorbents, since proteinious materials are likely to putrefy under moist conditions. Further, most metal sorption reported in literature is based on algal and fungal biomass, which must be cultured, collected from their natural habitats and pre-processed, if available as discards and transported under special conditions, thus introducing the factor of additional costs. In contrast, bgh as an agro-industrial waste has negligible cost and has also proved to be an efficient biosorbent for the removal of $\mathrm{Cr}$ (VI) ions.

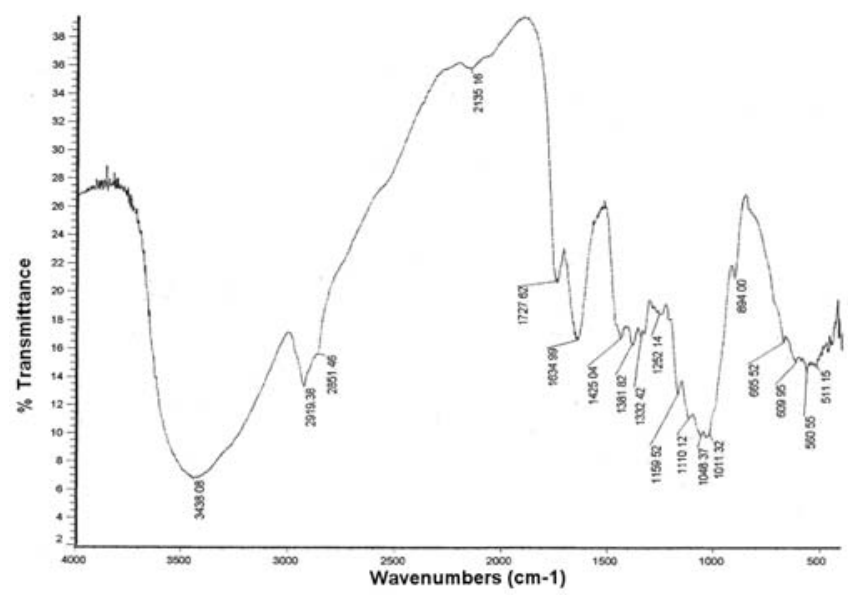

Figure 8. Infrared spectra of bgh reacted with $100 \mathrm{mg} / \mathrm{Cr}$ (VI) solution.

\section{ACKNOWLEDGEMENTS}

We thank the USIC facility, Karnatak University, Dharwad for their help with infra-red spectroscopy.

\section{REFERENCES}

AMIR, Hossein Mahvi; DARIUSH, Naghipour; FORUGH,
Vaezi and SHAHROKH, Nazmara. Teawaste as an adsorbent for heavy metal removal from industrial wastewaters. American Journal of Applied Sciences, 2005, vol. 2, no. 1, p. 372-375.

BAI, Sudha R. and ABRAHAM, Emilia. Studies on chromium (VI) adsorption-desorption using immobilized fungal biomass. Bioresource Technology, March 2003, vol. 87 , no. 1 , p. $17-26$.

BAI, Sudha R. and ABRAHAM, Emilia. Biosorption of $\mathrm{Cr}$ (VI) from aqueous solution by Rhizopus nigricans. Bioresource Technology, October 2001, vol. 79, no. 1, p. 73-81.

CETINKAYA DONMEZ, G.; AKSU, Z.; OZTURK, A. and KUTSAL, T. A comparative study on heavy metal biosorption characteristics of some algae. Process Biochemistry, October 1999, vol. 34, no. 9, p 885-892.

CHONG, K.H. and VOLESKY, B. Description of 2-metal biosorption equilibria by Langmuir-type models. Biotechnology and Bioengineering, 1995, vol. 47, no. 4, p. 451-460.

CHUBAR, Natalia; CARVALHO, Jorge R. and NEIVA CORREIA, M.J. Cork Biomass as biosorbent for $\mathrm{Cu}$ (II), $\mathrm{Zn}$ (II) and $\mathrm{Ni}$ (II). Colloids and Surfaces A: Physicochemical and Engineering aspects, December 2003, vol. 230, no. 1-3, p. 57-65.

CIESLAK-GOLONKA, Maria. Toxic and mutagenic effects of chromium (VI). Polyhedron, August 1996, vol. 15 , no. 21 , p. $3667-3918$.

DAKIKY, M.; KHAMIS, M.; MANASSRA, A. and MEREB, M. Selective adsorption of chromium (VI) in industrial wastewater using low-cost abundantly available adsorbents. Advances in Environmental Research, October 2002, vol. 6, no. 4, p. 533-540.

De FILIPPIS, L.F. and PALLAGHY, C.K. Heavy metals: sources and biological effects. In: RAI, L.C.; GAUR, J.P. and SOEDER, C.J. eds. Advances in Limnology Series: Algae and Water Pollution, E. Scheizerbartsche Press, Stuttgart, 1994, p. 31-77.

EATON, A.D.; CLESCERI, L.S. and GREENBERG, A.E. Standard Methods for the Examination of Water and Wastewater. $19^{\text {th }}$ ed. American Public Health Association Washington, DC, 1995. 1325 p. ISBN 0875532233.

ESPINOLA, A.; ADAMIAN, R. and GOMES, L.M.B. An innovative technology: natural coconut fibre as adsorptive medium in industrial wastewater cleanup. Proceedings of the TMS Fall Extraction and Processing Conference, 1999, vol. 3, p 2057-2066.

FREUNDLICH, H. Ueber die Adsorption in Loesungen. 
Zeitschrift fr Physikalische Chemie, 1907, vol. 57 A, p. 385-470.

IQBAL, M.; SAEED, A. and AKHTAR, N. Petiolar feltsheath of palm: a new biosorbent for the removal of heavy metals from contaminated water. Bioresource Technology, January 2002, vol. 81, no. 2, p. 153-155.

JUANG, R.S. and SHIAU, R.C. Metal removal from aqueous solutions using chitosan -enhanced membrane filtration. Journal of Membrane Science, February 2000, vol. 165 , no. 2 , p. $159-167$.

KADIRVELU, K. and NAMASIVAYAM, C. Agricultural by-products as metal adsorbents: sorption of lead (II) from aqueous solutions onto coir-pith carbon. Environmental Technology, 2000, vol. 21, no. 10, p. 1091-1097.

LANGMUIR, I. The adsorption of gases on plane surfaces of glass, mica and platinum. Journal of the American Chemical Society, 1918, vol. 40, no. 9, p. 1361-1403.

MARSHALL, W.E. and CHAMPAGNE, E.T. Agricultural byproducts as adsorbents for metal ions in laboratory prepared solutions and in manufacturing wastewater. Journal of Environmental Science and Health - Part A Environmental Science and Engineering, 1995, vol. 30, no. 2, p. 241-261.

McKAY, G.; BLAIR, H.S. and GARDENER, J.R. Adsorption of dyes on chitin I. Equilibrium studies. Journal of Applied Polymer Science, 1982, vol. 27, no. 8, p. 30433057.

MELO, M. and Ď'SOUZA. S.F. Removal of chromium by mucilaginous seeds of Ocimum Basilicu. Bioresource Technology, June 2004, vol. 92, no. 2, p. 151-155.

NIYOGI, S.; ABRAHAM, E.T. and RAMAKRISHNA, S.V. Removal of chromium (VI) ions from industrial effluents by immobilized biomass of Rhizopus arrhizus.Journal of Scientific and Industrial Research, 1998, vol. 57, no. 10-11, p. 809-816.

PRAKASHAM, R.S.; MERRIE, J.S.; SHEELA, R.; SARASWATI, N. and RAMAKRISHNAN, S.V. Biosorption of Chromium (VI) by free and immobilized Rhizopus arrhizus. Environmental Pollution, 1999, vol. 104, no. 3, p. 421-427.

PURANIK, P.R. and PAKNIKAR, K.M. Biosorption of lead, cadmium and zinc by citrobacter strain MCMB-181: Characterization studies. Biotechnology Progress, 1999, vol. 15 , no. 2, p. 228-237.

SAEED A, IQBAL M. and AKHTAR M.W., Application of biowaste materials for the sorption of heavy metals in contaminated aqueous medium. Pakistan Journal of Scientific and Industrial Research, 2002, vol. 45, no. 3, p.
206-211.

TEIXERIA TARLEY, Cesar Ricardo and ZEZZI ARRUDA, Marco Aurélio. Biosorption of heavy metals using ricemilling by-products. Characterisation and application for removal of metals from aqueous solutions. Chemosphere, February 2004, vol. 54, no. 7, p. 905-915.

UCUN, Handan; KEMAL, Bayhan Y.; YUSUF, Kaya; AVNI, Cakici and FARUK, Algur O. Biosorption of chromium (VI) from aqueous solution by cone biomass of Pinus sylvestris. Bioresource Technology, November 2002, vol. 85 , no. 2 , p. $155-158$.

VOLESKY, B. and HOLAN, Z.R. Biosorption of heavy metals. Biotechnology Progress, 1995, vol. 11, no. 3, p 235-250.

YAN, G. and VIRARAGHAVAN, T. Heavy metal removal in a biosorption column by immobilized $M$. rouxii biomass. Bioresource Technology, July 2001, vol. 78, no. 3, p. 243249. 